\title{
Western Economic Sanctions against Russia: an Opportunity for Closer Eurasian Integration?
}

Damien Boucher ${ }^{1}$

\begin{abstract}
:
The policy implemented by the Russian Federation over the past five years has been significantly independent from the contemporary world order's approach, which led to Russia being relatively isolated from the international community. This situation of isolation is primarily reflected by the sanction regime that is now implemented against Russia.

Given that the United States of America (US) and the European Union (EU) represent the world's most powerful entities in terms of economy and often have the greatest influence on solving international issues, this article analyzes the economic sanctions they have implemented against Russia.
\end{abstract}

Key words: Russia, US, European Union, Economic sanctions, Eurasian integration.

\section{Overview of the US and European Union sanctions against Russia as part of the Ukrainian crisis}

The policy implemented by the Russian Federation over the past five years has been significantly independent from the contemporary world order's approach, which led to Russia being relatively isolated from the international community. This situation of isolation is primarily reflected by the sanction regime that is now implemented against Russia. Given that the United States of America (US) and the European Union (EU) represent the world's most powerful entities in terms of economy and often have the greatest influence on solving international issues, this article analyzes the economic sanctions they have implemented against Russia.

Nevertheless, it is important to note that other unilateral sanctions have been implemented by many other States (such as Japan, Norway or Switzerland), which

\footnotetext{
${ }^{1}$ Macroeconomic Analyst at the French Embassy in Russia.
} 
demonstrates the high mobilization of the international community. This paper focuses on the period beginning from the first sanctions implemented after the annexation of Crimea by Russia, and lasting until the victory of Donald Trump at the US elections on November 8th, 2016. The outcome of the US Presidential elections switched the focus to a potential interference of Russia in the American elections and became the main reason for the implementation of new sanctions.

In this analysis, the methodology from the Targeted Sanction Consortium ${ }^{2}$ (TSC) is used to distinguish three episodes of sanctions, based on the relative targeting degree of sanctions and their different goals: from sanctions against individuals (March 2014 - July 2014) to sectoral sanctions (July 2014 - March 2015) and sanctions conditional on implementing each clause of the Minsk Protocol (from March 2015). It is also important to mention that, overall, the sanctions implemented by the EU and the US are similar, which shows they cooperatively try to achieve the same political results. According to the TSC methodology, these results can be seen in terms of coercion (change Russia's behavior), constraint (limit Russia's actions that do not comply with international law), and signaling (stigmatize Russia as a transgressor of international law in the eyes of the international community).

As regards to the first episode of the sanction regime, the implementation of individual economic sanctions by the $\mathrm{US}^{3}$ and the $\mathrm{EU}^{4}$ right after the annexation of Crimea by the Russian Federation had several goals. In this episode, very precise targeting instruments were mostly used, such as individual and corporate asset freeze. On March 17th 2014, the US Office of Foreign Assets Control (OFAC) added 12 individuals on the Specially Designated Nationals list (SDN list) after the events in Ukraine, including the former President of Ukraine, Victor Yanukovych. Similarly, on the first decision of the Council of the European Union on March 17th 2014, 21 individuals, whose actions

\footnotetext{
${ }^{2}$ Biersteker, T., Eckert, S., \& Tourinho, M. (2016). Targeted Sanctions: The Impacts and Effectiveness of United Nations Action. Cambridge: Cambridge University Press.

3 Executive Order 13661 (19 March 2014), U.S. Federal Register, 79, 53.

${ }^{4}$ Council Decision 2014/145/CFSP of (17 March 2014).
}

Orientando. Temas de Asia Oriental. Sociedad, Cultura y Economía. Revista editada por el Centro de Estudios China-Veracruz de la Universidad Veracruzana, México (Centro de Estudios APEC) / año 10 / número 19/ 
participated in "threatening the territorial integrity, sovereignty and independence of Ukraine" became subject of an asset freeze in the EU.

These lists have expanded over time and, at the end of the episode when sectoral sanctions began in July 2015, the EU had already implemented asset freeze against 30 legal entities and individuals6. In the meantime, the US SDN list included 148 legal entities and individuals ${ }^{7}$ following amendments of President Obama's Executive Order dated March 16 2014. These sanctions aimed at weakening the support granted by the powerful political, corporate and military establishment to Russian central authorities for their strategy in Crimea, as well as in Ukraine in general. During this episode, in terms of forcing Russia to change its behavior and limit its confrontational strategy, it is not possible to say that these sanctions proved to be effective. Indeed, Russian authorities did not change their position or strategy about Crimea and the talks between France, Germany, Ukraine and Russia (Normandy format) did not lead to significant results. Nevertheless, Russia effectively became a transgressor of international law in the eyes of the international community and these individual sanctions proved to be relatively effective in stigmatizing Russia.

In July 2014, the second episode of sanctions began with sanctions targeting sectors, access to finance and goods. This episode ended in March 2015 when the lifting of sanctions became formally linked with the implementation of the Minsk Agreements. The evaluation in terms of effectiveness of these sanctions is more positive than the evaluation of individual sanctions because, in addition to the success achieved in stigmatizing Russia, the objectives of forcing Russia to change its strategy and restrain its illegal actions were also partly achieved.

For example, Russia withdrew from South-East Ukraine a range of heavy weapons (Minsk Protocol, September 5, 2014 ${ }^{8}$ ), Russia participated in a new round of negotiation

\footnotetext{
${ }^{5}$ Ibid.

${ }^{6}$ Council Decision 2014/308/CFSP (28 May 2014) and Council Decision 2014/455/CFSP (11th July 2014).

${ }^{7}$ Office of Foreign Assets Control (OFAC) Sanctions List Search, UKRAINE-EO13661.

${ }^{8}$ Article 2 of the Minsk Agreement, Financial Times, Full text of the Minsk agreement, 12th February 2015.
}

Orientando. Temas de Asia Oriental. Sociedad, Cultura y Economía. Revista editada por el Centro de Estudios China-Veracruz de la Universidad Veracruzana, México (Centro de Estudios APEC) / año 10 / número 19/ 
as part of the Minsk Agreements (February $122015^{9}$ ) and the conflict did not expand further than the ceasefire line agreed as part of the Minsk Protocol. In order to limit Russia's economic opportunities, a new type of economic sanctions were implemented by the US against Russia through the creation of the Sectoral Sanctions Identifications list (SSI list). Directives 1 and 2 of the Executive Order 13662 dated March 242014 published by OFAC on July $162014^{10}$ formulated financial constraints forbidding American entities and individuals to carry out operations with a number of Russian counterparts involving debt with maturity from 30 to 90 days or equity. These constraints complicated access to financial resources, especially in US dollar, for Russian companies.

Such decision was based on the fact that accessing foreign financial resources has a great influence on companies' abilities to develop and face international competition and has a strong potential to hinder Russia's economic performance. In September 2014, the US strengthened sectoral sanctions by defining new constraints for American individuals and entities aimed at Russia's oil and gas sector ${ }^{11}$, which is a key sector for the Russian economy. These constraints include exporting products, services and technology to support certain types of projects related to oil exploration and extraction activities in Russia. For its part, the EU implemented sectoral sanctions against Russia and abandoned economic cooperation in several areas in July 2014. In September 2014, similarly to the US, the EU strengthened these sanctions.

These sanctions aimed at restraining access of Russian counterparts to European markets, services and technologies. Sectoral sanctions include restriction measures for several Russian banks and corporates to access European primary and secondary capital markets, forbid exports and imports of weapons, forbid exports of dual-use goods that could have a military use, and limit the access to sensitive technologies and services linked with oil exploration and exploitation activities. In addition, apart from withdrawing from several bilateral and regional programs of cooperation with Russia ${ }^{12}$, the EU also

\footnotetext{
9 Package of Measures for the Implementation of the Minsk Agreements, OSCE (https://www.osce.org/cio/140156).

${ }^{10}$ Directive 1 and 2 of Executive order 13662 (24 March 2014), US Federal Register, 79, 56.

${ }^{11}$ Ibid., Directive 3.

12 "EU restrictive measures in response to the crisis in Ukraine", Council of the European Union (http://www.consilium.europa.eu/en/policies/sanctions/ukraine-crisis/).
}

Orientando. Temas de Asia Oriental. Sociedad, Cultura y Economía. Revista editada por el Centro de Estudios China-Veracruz de la Universidad Veracruzana, México (Centro de Estudios APEC) / año 10 / número 19/ 
decided to stop a great part of its economic cooperation with the Russian Federation when it imposed in July 2014 to the European Investment Bank (EIB) and to the European Bank for Reconstruction and Development (BERD) to stop financing new projects in Russia13. The US and the EU also introduced restrictive measures concerning trade, investment and tourism on the territory of Crimea and Sevastopol14. It is important to note that the coordinated policy from the EU and the US in constraining key sectors of the Russian economy has played an important role to assess the impact of these sanctions as effective.

To this day, all these restrictive measures are still in place, and many of them tightened. However, the lifting of economic sanctions implemented by the EU is formally linked with the full implementation of the second Minsk Agreement ${ }^{15}$ from March 19th $2015^{16}$. This means that the EU will take the decision to extend the sanctions as long as the Minsk Agreements has not been fully implemented. With this formal linkage, the strategy of achieving political objectives through economic sanctions becomes obvious and it is easy to assess their effectiveness by looking at the implementation or nonimplementation of the measures laid out in the Minsk Agreements.

From the moment of the this formal linkage, giving to Russia great incentives to stop its confrontational strategy against Ukraine and against the international community, until the victory of Donald Trump at the US elections, there has not been significant progress in settling the situation in Ukraine and implementing the Minsk Agreements. This implies that the sanctions did not prove to be particularly effective. For example, the key measure about the "withdrawal of all foreign-armed formations, military equipment, as well as mercenaries from the territory of Ukraine" ${ }^{17}$ was not fulfilled and this demonstrates that the sanctions did not prove effective in forcing Russia to change its strategy.

\footnotetext{
13 "Statement by President Barroso and President Van Rompuy in the name of the European Union on the agreed additional restrictive measures against Russia", 29 July 2014, European Commission (http://europa.eu/rapid/press-release_STATEMENT-14-244_en.htm).

${ }^{14}$ Council Regulation (EU) 1351/2014 (18 December 2014) and Executive order 13685 (24 December 2014), US Federal Register, 79, 247.

15 Package of Measures for the Implementation of the Minsk Agreements, OSCE (https://www.osce.org/cio/140156).

${ }^{16}$ European Council meeting (19 and 20 March 2015 ) - Conclusions, 20 March 2015, European Council.

${ }^{17}$ Article 10 of the Minsk Agreement, Financial Times, Full text of the Minsk agreement, 12 February 2015.
}

Orientando. Temas de Asia Oriental. Sociedad, Cultura y Economía. Revista editada por el Centro de Estudios China-Veracruz de la Universidad Veracruzana, México (Centro de Estudios APEC) / año 10 / número 19/ 
Moreover, Hungarian Prime Minister Viktor Orban's statement about his potential refusal to extend sanctions against Russia ${ }^{18}$ and Greek Prime Minister Alexis Tsipras's view of sanctions against Russia as a "vicious cycle" 19 is an evidence of the weakening influence of sanctions in stigmatizing Russia. In terms of restraining military activity on the territory of Ukraine and concerning the expansion of the conflict zone, the assessment about the effectiveness of sanctions is mixed. The signing in early 2015 of the Minsk Agreements helped to reduce military confrontation between Ukrainian troops and separatists (in January 2015, they were fighting for Donetsk airport, and in October 2015, they withdrew weapons), but military activity increased at the end of the year from November 92015 (direct clashes erupted a few months after agreeing on a ceasefire, and Ukrainian authorities talked about the escalation of violence around Donetsk)20. Again, during summer 2016, military activity on the territory of Ukraine increased (the UN reported June as the "deadliest month for Easter Ukraine since August 2015"21) and this demonstrates that, even though the formal linkage of European sanctions with the Minsk Agreements seemed effective at the beginning, it did not prove to be so effective in the longer term.

The economic sanctions implemented by the US and the EU did not help achieve significant progress as regards to the political goals of settling the situation on the territory of Ukraine and forcing Russia to change its confrontational strategy against Ukraine and, in a broader sense, against a great part of the international community. By definition, economic sanctions aim at harming the economy of a State in order to induce a change of behavior. Logically, if the degree of negative impact of sanctions on the economy of a country is not significant, then ambitious political goals are unlikely to be achieved. That is why, it is a priority to analyze the impact of sanctions on the development of the Russian

\footnotetext{
189 December 2015, "EU Anti-Russia Sanctions Extension Not Vetoed by Hungary, Greece", Sputnik News, (https://sputniknews.com/europe/201512091031499121-hungary-greece-veto-sanctions/).

198 April 2015, "Tsipras calls for end to 'vicious cycle' of sanctions after talks with Putin", France 24 (http://www.france24.com/en/20150408-greece-russia-putin-tsipras-talks-sanctions-financial-aid).

20 The Ukraine Crisis Timeline \#276 (9 November 2015, "Ukraine Sees First Direct Engagements in Months"), \#278 (10 November 2015, "Reports Indicate Increased Fighting Despite Ceasefire") и \#280 (15 November 2015, "Ukrainian Military Sees Escalation Around Donetsk"), Center for Strategic and International Studies (http://ukraine.csis.org).

${ }^{21}$ Ibid., \#459 (3 August 2016, "UN Report: June was Deadliest Month for Eastern Ukraine since August 2015").
}

Orientando. Temas de Asia Oriental. Sociedad, Cultura y Economía. Revista editada por el Centro de Estudios China-Veracruz de la Universidad Veracruzana, México (Centro de Estudios APEC) / año 10 / número 19/ 
economy in order to understand why the strategy of the Russian Federation did not change.

Orientando. Temas de Asia Oriental. Sociedad, Cultura y Economía. Revista editada por el Centro de Estudios China-Veracruz de la Universidad Veracruzana, México (Centro de Estudios APEC) / año 10 / número 19/ 


\section{Impact of sanctions on the Russian economy}

Considering that Russia did not significantly change its approach to the conflict with Ukraine even though the EU and the US tried to increase the costs of Russia's confrontational strategy through economic sanctions, it is necessary to analyze Russian Federation's economic situation, in particular how it changed after the implementation of sanctions. In order to do so, it is important to take into account the retaliatory economic sanctions that Russia implemented in August $2014^{22}$ against States that took restrictive measures against Russia (notably EU member states, US, Canada, Australia and Norway). Russian authorities decided to impose an import ban on "agricultural production, materials and foodstuffs" ${ }^{\prime 23}$ from these countries, including a wide range of meat, dairy and fish products, vegetables and fruits.

It is interesting to mention the reference about "security" in the Presidential decree implementing the import ban because it clearly demonstrates the logic behind the implementation of counter sanctions from Russia tightly linked with the defense of strategic interests and the notion of economic security. These economic sanctions led to changes in the structure of international trade and financial operations between Russia and the rest of the world, as well as changes in the Russian economy's internal structure. It is necessary to focus on each of these aspects separately in order to measure the impact of the sanctions on the development of the Russian economy as a whole from the start of the implementation of US and EU economic sanctions in March 2014 until the end of 2017 third quarter. Moreover, it is particularly important to isolate the concrete effect of economic sanctions from the effect of exogenous factors that influenced Russian economy at the same moment. In particular, the sagging demand on the Russian market was not only a consequence of sanctions, but also the result of the decrease of oil prices and Russian ruble's exchange rate compared to the euro and the dollar.

\footnotetext{
${ }^{22}$ Decree of the President of the Russian Federation dated 6 August 2014 N 560 « On the implementation of specific economic measures aiming at ensuring the security of the Russian Federation”, 7 August 2014, 6448, 176.

${ }^{23}$ Ibid., Article 1.
}

Orientando. Temas de Asia Oriental. Sociedad, Cultura y Economía. Revista editada por el Centro de Estudios China-Veracruz de la Universidad Veracruzana, México (Centro de Estudios APEC) / año 10 / número 19/ 
First of all, the structure and the total value of trade between Russia and the world changed quite significantly. Between 2013 and 2016, Russia's total trade turnover decreased by $45 \%$ and was still down by $31 \%$ at the end of 2017 compared to 2013 . Both exports and imports were similarly affected as shown in Graph 1.

Graph 1. Total trade in goods between Russia and the world (bn USD)

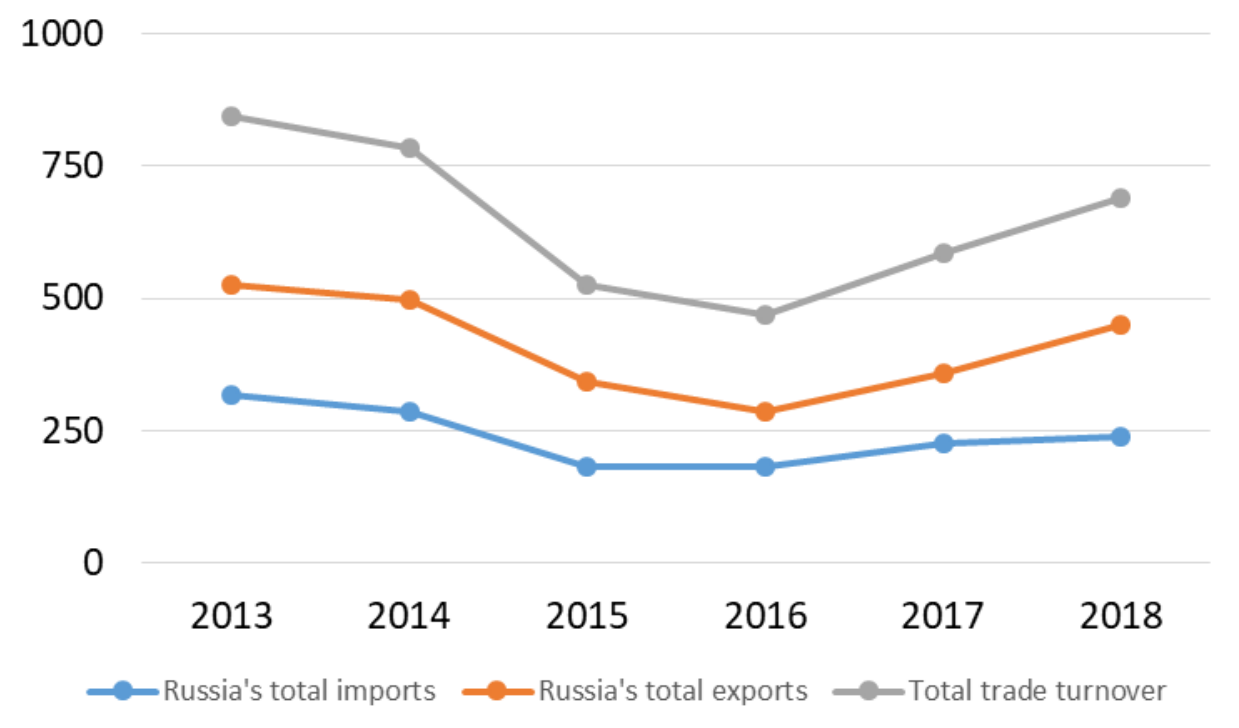

Source: Federal Customs Service of the Russian Federation.

Taking a closer look at Russia's biggest trade partner, the European Union, the rapid fall of its share in total Russian imports is noticeable, decreasing from $42 \%$ at the end of 2013 to $38 \%$ in 2015, before stabilizing around that level until today (Graph 2).

In value, trade turnover between Russia and the EU decreased every year between 2013 and 2016 and was down by 52\% in 2016 compared to 2013 (200 bn USD vs 417 bn USD), before bouncing back in 2017 with a 23\% increase y.o.y. Analyzing the fall of EU share of imports in total Russian imports by member states (Graph 3), an important element to notice is that imports slowed quite evenly from most of EU member states in 2014, 2015 and 2016.

On the other hand, China seems to have benefited a lot from the falling share of imports from EU countries (Graph 4). Indeed, imports of Chinese goods by Russia increased almost symmetrically to the decrease of imports from the EU. These numbers make a good case in favor of the idea that economic sanctions between Russia and the

Orientando. Temas de Asia Oriental. Sociedad, Cultura y Economía. Revista editada por el Centro de Estudios China-Veracruz de la Universidad Veracruzana, México (Centro de Estudios APEC) / año 10 / número 19/ 
EU are responsible for a huge decrease in mutual trade and disrupted quite heavily Russia's economy.

Graph 2. Share of imports from EU countries in total Russian imports $45 \%$

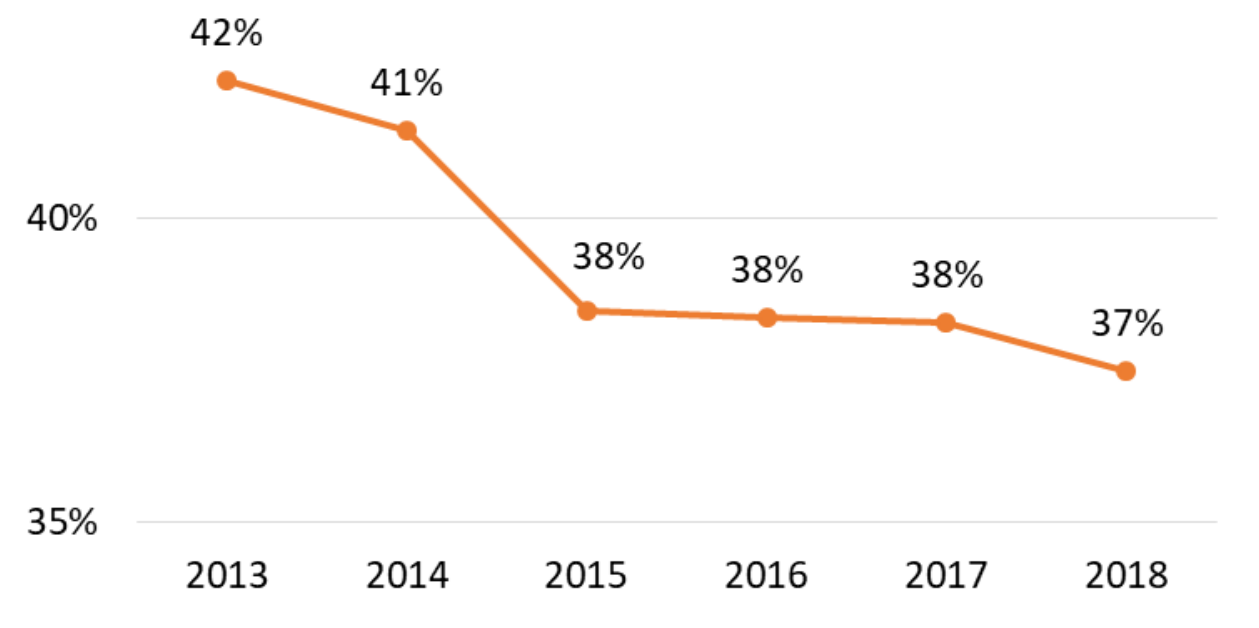

Source: Federal Customs Service of the Russian Federation.

Orientando. Temas de Asia Oriental. Sociedad, Cultura y Economía. Revista editada por el Centro de Estudios China-Veracruz de la Universidad Veracruzana, México (Centro de Estudios APEC) / año 10 / número 19/ 
Graph 3. Share of imports from EU countries in total Russian imports by member states

Orientando. Temas de Asia Oriental. Sociedad, Cultura y Economía. Revista editada por el Centro de Estudios China-Veracruz de la Universidad Veracruzana, México (Centro de Estudios APEC) / año 10 / número 19/ 
$14 \%$

$12 \%$

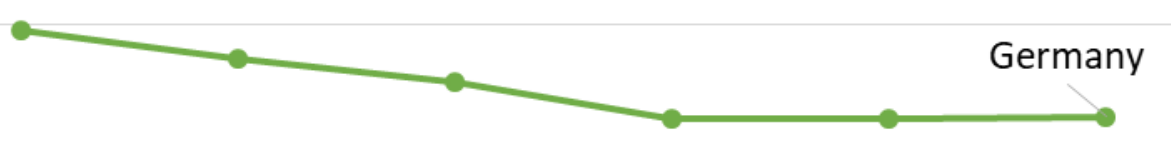

$10 \%$

$8 \%$

$6 \%$

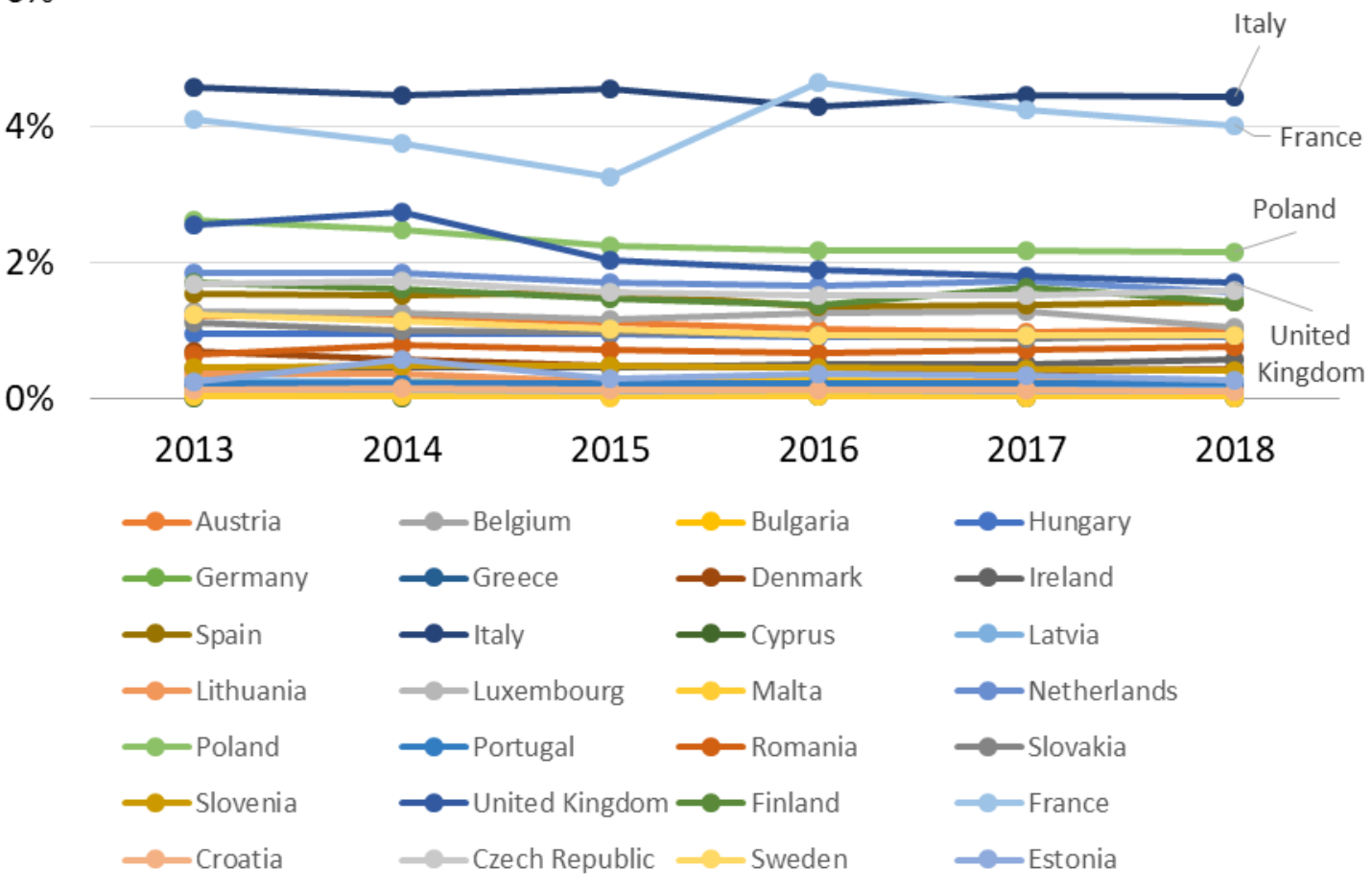

Source: Federal Customs Service of the Russian Federation.

Orientando. Temas de Asia Oriental. Sociedad, Cultura y Economía. Revista editada por el Centro de Estudios China-Veracruz de la Universidad Veracruzana, México (Centro de Estudios APEC) / año 10 / número 19/ 


\section{Graph 4. Share of imports from Russia's top 3 trade partners in total Russian imports} $45 \%$

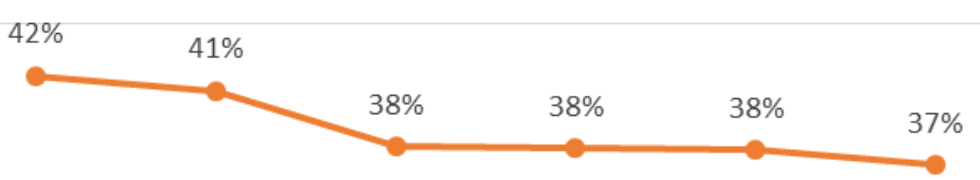

$30 \%$
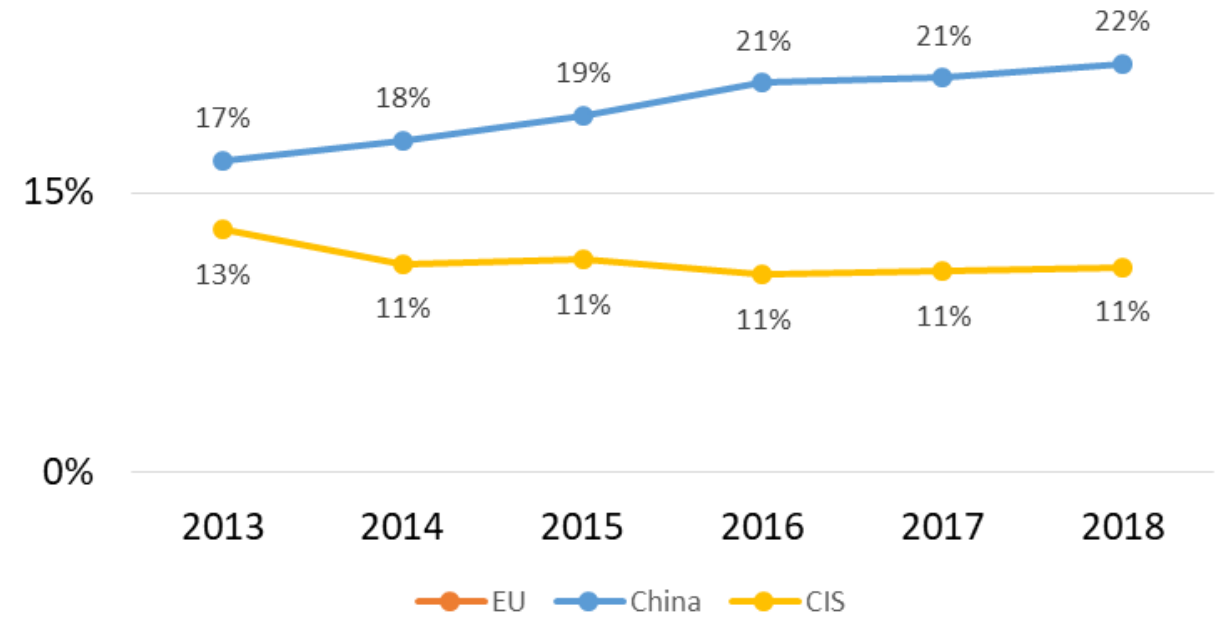

Source: Federal Customs Service of the Russian Federation.

It is, however, necessary to be very careful in analyzing these statistics in order to avoid making mistakes about the causes of such changes. Comparing the decrease in trade volume between Russia and the EU between 2013 and 2016 (52\%) with the fall of Russia's overall trade turnover during the same period (45\%), the situation does not look so alarming. Moreover, even though the majority of economic sanctions between Russia and the EU remain in force until this day, trade turnover has increased significantly from 2016: after a 23\% increase in 2017 compared to 2016, trade turnover confirmed its trend in 2018 with a $19 \%$ increase compared to 2017.

It is clear that changes to the value and structure of external trade are the result of many factors, and are not only caused by economic sanctions. Using the gravitational 
model that takes into account the size of the economy and the distance between economies and is traditionally used to forecast bilateral trade between two countries, Hinz tried to isolate the effect of sanctions to explain the decrease of Russia's trade. He estimates that the sanctions implemented by the EU as well as Russia's retaliatory measures are responsible for 62.94 bn USD worth of loss in mutual trade between the beginning of 2014 and the end of $2015^{24}$. For its part, the European Commission stresses the limited impact of the sanctions against Russia on the European economy because it estimates the effect at $-0.3 \%$ on EU GDP for 2014 and $-0.4 \%$ for $2015^{25}$.

According to the Russian Academy of Science, the greatest part of the negative effect of sanctions on Russia's economy is not the result of the import and export ban decided by both parties, but comes from the restrictive financial measures that disrupt access to finance for Russian companies as well as from the indirect effects of sanctions. Such effects include higher inflation on the internal market, potential decrease of oil exports because of restricted access to necessary financial resources and technologies to create new oil exploitation projects, and many more. These effects must be analyzed in more details to get a clear picture of the situation.

As regards financial sanctions implemented by the US and the EU, their consequences proved to be more significant than measures restricting trade for Russian companies and Russia's economy. In the period from 2014 to 2017, Russia's attractiveness for foreign investments worsened significantly. At the end of 2017, direct, portfolio and other investments in Russia decreased by 5\%, 16\% and 39\% respectively compared to the end of $2013^{26}$. This means that overall inflows of foreign financial capital in Russia strongly decreased during this period by around 269 bn USD.

Similarly to issues regarding trade, other exogenous effects must be accounted for because the decrease of foreign financial inflows does not necessarily only result from

\footnotetext{
${ }^{24}$ Hinz, J., November 2017, " The cost of sanctions: Estimating lost trade with gravity ", Kiel Working Papers, Kiel Institute for the World Economy (IfW), No 2093.

${ }^{25}$ Norman, L., 29 October 2014, "EU Projects Impact of Sanctions on Russian Economy", Wall Street Journal (https://www.wsj.com/articles/eu-projects-impact-of-sanctions-on-russian-economy1414583901).

${ }^{26}$ International investment position of the Russian Federation in 2017, Liabilities, CBR, 2013 and 2017
}

Orientando. Temas de Asia Oriental. Sociedad, Cultura y Economía. Revista editada por el Centro de Estudios China-Veracruz de la Universidad Veracruzana, México (Centro de Estudios APEC) / año 10 / número 19/ 
economic sanctions. Nevertheless, sanctions played an important role in shaping this dynamic not only through direct effects of the investment ban, but also through their indirect effects of increasing uncertainty for investors, concerns about an escalation of the tension, and a range of other consequences.

Already in 2015, Gurvich and Prilepsky ${ }^{27}$ published a complex analysis with an estimation of the potential effect of financial sanctions on Russia's economy. They estimated that the overall negative effect of financial sanctions on the gross capital inflows into the Russian economy was about 280 bn USD over 4 years from 2013 to 2017, which is similar to the empirical observation.

Analyzing the dynamic of assets of the Russian Federation for the same category (direct investments, portfolio investments and other investments from Russian to foreign counterparts), shows that Russia's net international investment position increased by an amount of around 136 bn USD between 2017 and $2013^{28}$. This is mainly explained by the fact that inflows of foreign capital into Russia decreased significantly faster than outflows from Russia to the rest of the world. However, the greatest part of this effect, especially for assets but also for liabilities, is accounted for as "revaluation" and not "operation"29. This implies that sanctions and uncertainty of investors did not played the greatest role in making changes to Russia's investment position, as opposed to other factors impacting the valuation of Russian assets.

Even though sanctions affected Russia's economy through their indirect effects (decrease of foreign direct investments, restricted access to credit for Russian companies, etc.) on companies and sectors not directly targeted by sanctions, the fall of oil prices, and their low level from 2014 to 2017, must be pointed out. The fall of oil prices from

\footnotetext{
${ }^{27}$ Gurvich, E.T, Prilepsky, I.V., 2016, ""Vliyaniye finansovih sanktsiy na rossiyskooyoo ekonomikoo", Voprosi ekonomiki, 1, 5-35.

${ }^{28}$ International investment position of the Russian Federation in 2017, Liabilities, CBR, 2013 and 2017.

${ }^{29}$ Between 2014 and 2017, changes of financial assets of the Russian Federation as a result of revaluation amounted for $134 \%$ of overall changes, and changes as of result of operations (-18\%) partly offset this dynamic. Changes of financial liabilities of the Russian Federation as a result of revaluation amounted for $61 \%$ of overall changes, and changes as a result of operations amounted for $47 \%$. Source: Assets and Liabilities of the Russian Federation, International investment position of the Russian Federation in 2017, $C B R$.
}

Orientando. Temas de Asia Oriental. Sociedad, Cultura y Economía. Revista editada por el Centro de Estudios China-Veracruz de la Universidad Veracruzana, México (Centro de Estudios APEC) / año 10 / número 19/ 
their peak of 110 USD per Brent barrel in June 2014 to 49 USD in January 2015 coincided with the implementation of the first restrictive measures against Russia as part of the conflict with Ukraine.

This exogenous factor, and the fact that oil and gas is a key sector of Russia's economy, explains why it is so difficult to isolate the sole effect of sanctions. In May 2015, after a short period of oil prices growth to 66 USD per barrel, prices fell again almost continuously until January 2016, reaching their minimum at 29 USD per barrel. Oil prices remained under 60 USD per barrel until October 2017 and, considering the dependency of the Russian economy and of the State budget to oil and gas revenues, such oil prices had a very negative influence on the Russian economy. In fact, Gurvich and Prilepsky forecasted, with an analysis using a similar scenario to the one that took place (oil prices around 50 USD per barrel from 2015 to 2017), that a long period of low oil prices had a very negative influence on Russian GDP amounting to around 8.5 growth percentage points from 2014 to 2017. This estimation is significant compared to the sole effect of financial sanctions on the real economy estimated at about $2.4 \%$ of 2013 GDP from 2014 to 2017.

It is also interesting to compare the effect of sanctions with the effect of a decrease of oil prices in terms of exchange rate between Russian ruble and US dollar. Dreger et al. $(2016)^{30}$ estimate, for example, that the decrease of oil prices explain $12 \%$ of the decrease of the value of the ruble after a 1-month adaptation period, while sanctions only explain $1 \%$. Their work demonstrates that the ruble's exchange rate changes mostly as a result of a change of oil prices, and that the short-term effect of sanctions is comparatively much less significant. In a broader approach, the International Monetary Fund ${ }^{31}$ and Tuzova et al. $(2015)^{32}$, for example, also note the significant effect of oil prices fluctuation on the Russian economy. Therefore, even though the negative impact of sanctions proved more significant from a financial point of view than with regard to trade, it is clear that other

\footnotetext{
${ }^{30}$ Dreger, C., Kholodilin, K., Ulbricht, D., Fidrmuc, J., 2016, "Between the hammer and the anvil: The impact of economic sanctions and oil prices on Russia's ruble", Journal of Comparative Economics. 44, 2, 295-308.

${ }^{31}$ Russian Federation 2017 Article IV Consultation, IMF.

${ }^{32}$ Tuzova, Y., Qayum, F., 2016, "Global oil glut and sanctions: The impact on Putin's Russia", Energy Policy, 90, 140-151.
}

Orientando. Temas de Asia Oriental. Sociedad, Cultura y Economía. Revista editada por el Centro de Estudios China-Veracruz de la Universidad Veracruzana, México (Centro de Estudios APEC) / año 10 / número 19/ 
factors, especially oil prices, help to explain a great part of the negative development of Russia's economy over the last few years ${ }^{33}$. Considering this non-significant impact of sanctions on the Russian economy, it is not surprising that Russia's strategy did not substantially change with regard to the conflict with Ukraine.

Another interesting consequence of sanctions remains to analyze. Until now, the analysis has been focused on the impact of sanctions from an external point of view but it is also particularly important to study their impact on the internal structure of the Russian economy. Russia, as a result of its retaliatory restrictive measures implemented after US and EU sanctions, stopped importing a large range of agricultural products from the EU and the US and this can be analyzed as a situation similar to protectionism. Considering Russia's relative low competitiveness in food and agricultural industries on international markets, it is possible to see this type of protectionism as a protection of infant industries ${ }^{34}$. According to this theory, implementing trade barriers can help some weak economic sectors develop at their own pace before competing in international trade. However, sanctions from the EU and the US restrain access to finance and technology for Russian companies, which can lead to direct negative consequences such as decreasing oil or metal exploration, exploitation and exports that represent essential revenue sources for the Russian economy.

US and EU sanctions can also indirectly harm Russian companies in many sectors because they have a negative influence on business climate, they decrease the experience of cooperation between European, US and Russian companies, they lead company to minimize their risk by over complying with existing measures and many more. Thanks to the import ban implemented by Russia against many agricultural products from the EU and other partners, national agricultural production strongly increased ${ }^{35}$. There is no doubt

\footnotetext{
${ }^{33}$ Russia's economy growth rate in 2014: $-0,7 \%$ - in 2015: $-2,8 \%$ - in 2016: $-0,2 \%$. World Bank, GDP Growth (annual \%).

${ }^{34}$ The argument in favor of the defense of infant industries is that infant industries in many countries often do not achieve a similar level of economies of scale compared to companies from other countries. That is why they must be protected from competition against companies from other countries until they achieve a similar level of economies of scale. List, F., 1841, The National System of Political Economy.

3523 December 2017, " Rossijskoe sel'skoe xozyajstvo v 2017 godu: rekordy vopreki ", Ria Novosti (https://ria.ru/ny2018 resume/20171223/1511566139.html).
}

Orientando. Temas de Asia Oriental. Sociedad, Cultura y Economía. Revista editada por el Centro de Estudios China-Veracruz de la Universidad Veracruzana, México (Centro de Estudios APEC) / año 10 / número 19/ 
that Russian retaliatory measures allowed Russia's agricultural sector to develop ${ }^{36}$, but this positive consequence does not offset the numerous negative consequences of the sanction regime on Russia's economy as a whole.

As mentioned above, Russian counter-sanctions are similar to a protectionist regime and this does not allow Russia to actively participate in global value chains and modernize its economy. In that regards, one of the key challenge for the Russian economy is diversification because it would help decrease the dependency of the Russian economy to revenues from mineral resources. The sanction regime prevents solving this issue because, as noted by Zagashvili (2016) ${ }^{37}$, cooperation between the EU, the US and Russia as part of scientific and technological dialogue is necessary in order for Russian industry to develop. Furthermore, the development of the agricultural sector is not the ideal way to modernize the economy, considering the low level of value added of agricultural production. Sanctions and counter-sanctions have a significant impact on internal economic factors in the short and medium term through inflation, decrease of national demand, investment, and other data.

The greatest challenge for the Russian Federation under the sanction regime in the long term is the breakdown of scientific and technological dialogue with developed countries. Without such cooperation, Russia is unlikely to develop rapidly and modernize its economy. It is important not to underestimate the effect of experience and Western countries' ability to innovate from which Russia could economically benefit a lot with closer interaction and cooperation.

Even if there is no universal way to solve the task of economic modernization, Russia could gradually improve its production of goods with high value added or, in cooperation with other countries, develop innovations in sectors where it has high potential but this seems like a difficult task while sanctions are in force. For example, the creation of the innovation center Skolkovo and partnerships with transnational companies such as IBM,

\footnotetext{
${ }^{36}$ Foy, H., 3 September 2017, "Russian agriculture thrives as sanctions close off imports", Financial Times (https://www.ft.com/content/09632e20-88bf-11e7-8bb1-5ba57d47eff7).

${ }^{37}$ Zagashvili, V., 2016, "Diversifikaciya Rossijskoj ekonomiki v usloviyax sankcij", Mirovaya ekonomika i mezhdunarodnye otnosheniya, 60, 6, S. 58.
}

Orientando. Temas de Asia Oriental. Sociedad, Cultura y Economía. Revista editada por el Centro de Estudios China-Veracruz de la Universidad Veracruzana, México (Centro de Estudios APEC) / año 10 / número 19/ 
Siemens, Intel and Cisco represents clear illustrations of an attempt by Russian authorities to develop Russia's potential in designing technology with high value added in collaboration with the international community ${ }^{38}$.

Another example can be found in the oil and gas sector, where Russia plays a key global role: ExxonMobil and Rosneft signed agreements for the creation of a joint venture in 2013 and 2014 aiming at exploiting deep-water oil, shale oil, and oil located in remote areas, like in the Artic region. This partnership was broken up in 2018 because of sanctions ${ }^{39}$, which clearly demonstrates the negative impact of economic sanctions on the modernization of Russia's economy in the long term.

From many different points of view, economic sanctions against Russia are not the key factors explaining the dynamics of the Russian economy observed in the past few years. Oil prices prove indeed to better forecast the developments of the Russian economy. Nevertheless, the breakdown of relations between Russia and its EU and US counterparts as part of scientific and technological dialogue represents the most serious threat and obstacle for the modernization of the Russian economy in the long term because it affects all sectors and entities operating in the Russian economy. In the current context of the sanction regime that does not support mutual economic interests between Russia and its biggest partners, it is particularly interesting to study the potential evolution of relations in Eurasia in the medium and long term, especially focusing on the EU and China because they are Russia's most powerful neighbors.

\footnotetext{
${ }^{38}$ Buravtseva, M., 20 June 2012, "Krupnejshie partnery 'Skolkovo' xotyat dlya svoix R\&D centrov otdel'nuyu proceduru rassmotreniya", (https://www.vedomosti.ru/business/articles/2012/06/20/krupnejshie_partnery_skolkovo_hotyat_dlya_svo ih_rd_centrov).

${ }^{39}$ Foy, H., Crooks, E., 11 March 2018, "ExxonMobil abandons joint ventures with Russia's Rosneft", Financial Times (https://www.ft.com/content/7e6a3212-1d1c-11e8-956a-43db76e69936) .
}

Orientando. Temas de Asia Oriental. Sociedad, Cultura y Economía. Revista editada por el Centro de Estudios China-Veracruz de la Universidad Veracruzana, México (Centro de Estudios APEC) / año 10 / número 19/ 


\section{Development prospects of EU-Russian and Sino-Russian relations}

Despite economic sanctions, the EU is still Russia's most important trade partner in 2018 and EU-Russian trade turnover is by far superior to Chinese-Russian trade turnover (294 bn USD vs 108 bn USD in 2018). Moreover, Russia benefits a lot from trade with the EU since its trade balance surplus is worth almost 116 bn USD in 2018, and this is a structural parameter given EU's dependence on Russian energy supplies.

Another interesting parameter to study, however, is the evolution of Chinese-Russian trade relations from 2013 to 2018 . It is interesting to notice the continuous rise of ChineseRussian trade turnover compared to EU-Russian trade turnover: in 2013, Chinese-Russian trade turnover was $21 \%$ the size of EU-Russian trade turnover, but it was 37\% in 2018. In addition, the trade deficit that Russia was running with China gradually decreased between 2013 and 2017; and even turned into a surplus in 2018 (Graph 5). These developments means that trade relations between Russia and China have become better balanced and this situation suggests that Russia will be more interested in deepening its trade ties with China, especially at a time of tense relationship with EU partners.

\section{Graph 5. Evolution of Russia's trade balance with China}

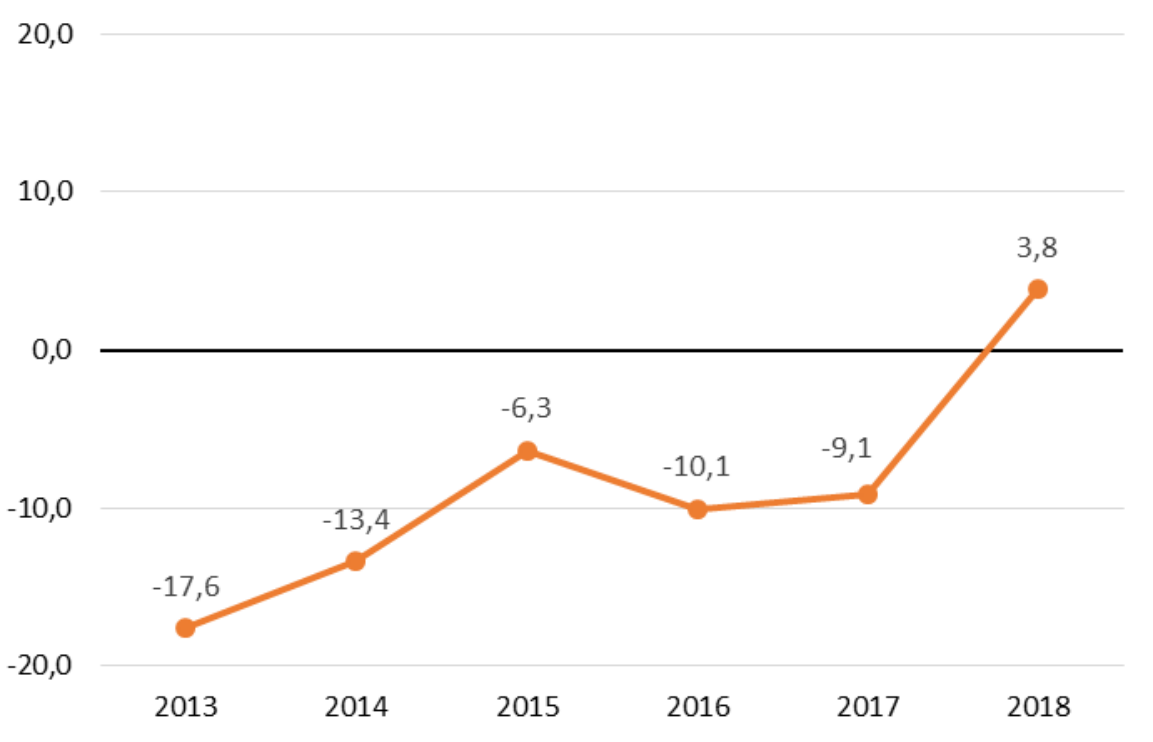

Source: Federal Customs Service of the Russian Federation.

Orientando. Temas de Asia Oriental. Sociedad, Cultura y Economía. Revista editada por el Centro de Estudios China-Veracruz de la Universidad Veracruzana, México (Centro de Estudios APEC) / año 10 / número 19/ 
From the EU perspective, Russia is the EU 4th most important client in terms of exports and the 3 rd most important supplier in terms of imports ${ }^{40}$. Given the deep mutual trade ties between Russia and the EU, the diplomatic tension and the deterioration of economic relations have a negative impact on both sides' economy. Accounting for the contemporary dynamics of slowing growth in Europe and rising contestation of mainstream politics, changes regarding the sanction regime implemented by the EU cannot be completely excluded. Some contemporary trends and political events indeed suggest that the EU might not tighten or even extend sanctions against Russia.

In terms of economic trends, the rapid increase of trade between the EU and Russia in 2017 and 2018 must be mentioned. In 2017, the 23\% y.o.y. increase of EU-Russian trade turnover was explained by a similar increase of both exports from Russia to the EU $(+22 \%)$ and imports from the EU to Russia (24\%). In 2018, EU-Russian trade turnover rose again by $19 \%$ y.o.y. (Russian exports $+28 \%$, Russian imports $+3 \%$ ). This development, observed despite the sanction regime remaining and tightening, suggests that the resumption of a positive trend in EU-Russian trade happened after a period of uncertainty for EU and Russian companies. However, it is once more necessary to mention the evolution of oil prices that presumably explains a great part of this trend. Oil prices gradually increased during 2017 and 2018 and yearly average price per Brent barrel increased respectively compared to the previous year by $24 \%$ and $32 \%{ }^{41}$. Comparing oil prices evolution with Russian exports to EU, that consist mainly of "mineral fuels, lubricants and related materials" (67\% of EU imports from Russia in 2017), a close similarity between both dynamics can be deduced. This element does not support the idea of a resumption of closer economic integration between Russia and the EU.

Nevertheless, it is important to notice that almost all types of exports from the EU to Russia rose in 2017, even food products and animals, which is surprising considering the import ban implemented by Russia on a wide range of agricultural products from the EU.

\footnotetext{
${ }^{40}$ Eurostat.

${ }^{41}$ Yearly average of Europe Brent Spot Price FOB (Dollars per Barrel), International Energy Agency.
}

Orientando. Temas de Asia Oriental. Sociedad, Cultura y Economía. Revista editada por el Centro de Estudios China-Veracruz de la Universidad Veracruzana, México (Centro de Estudios APEC) / año 10 / número 19/ 
In this context, it is expected that this tendency will make a rising number of companies and sectors willing to lobby in favor of the lifting of sanctions against Russia. This lobbying might decrease the support for a strategy of sanctions against Russia that is for now shared by a majority of EU representatives.

Some elements show that this support might be fading. A range of political declarations shows that several EU countries do not want to tighten sanctions against Russia. In this regard, it is important to mention official declarations of the European Commission and of some of the most powerful EU countries, including Germany, in June $2017^{42}$ where they clearly stated their opposition to the US project of tightening sanctions in the energy sector. EU energetic dependency from Russian supplies of hydrocarbon resources is a clear example where EU economic interests do not coincide with US interests. This situation, explained by geographic proximity and historical infrastructure, demonstrates the subtlety between achieving political objectives and bearing economic costs. In this case, the prospect of new sanctions from the US against Russia threatened the energy security of the EU, and thus more broadly the economic security of the EU.

The EU is therefore not ready to bear such high costs in its plans of forcing Russia to change its strategy regarding Ukraine. This can mean that tightening EU sanctions is no more possible because of the close economic interests linking Russia and the EU, where both of them benefit from the development of economic relations and suffer from restrictive measures. Indeed, the recent declarations of some European countries' leaders suggests that EU policy against Russia has lost support among EU member states.

As already mentioned, Greece and Hungary expressed doubts in 2015 regarding the current policy of sanctions against Russia. Furthermore, Greek Prime Minister Alexis Tsipras reiterated his position in 2016, stating his preference for a policy of dialogue as opposed to a policy of sanctions ${ }^{43}$, and others EU leaders stated similar views. It is the case of Slovak Prime Minister in August 2016 who declared, after a meeting with Putin

\footnotetext{
${ }^{42}$ Francis, D., 15 June 2017, "Germany Hits Back at Possible New U.S. Sanctions on Russia", Foreign Policy (http://foreignpolicy.com/2017/06/15/germany-hits-back-at-possible-new-u-s-sanctions-on-russia/) 4328 May 2016, "Greece's Tsipras condemns sanctions against Russia", $B B C$ (http://www.bbc.com/news/world-europe-36403129).
}

Orientando. Temas de Asia Oriental. Sociedad, Cultura y Economía. Revista editada por el Centro de Estudios China-Veracruz de la Universidad Veracruzana, México (Centro de Estudios APEC) / año 10 / número 19/ 
in Moscow, that both Russia and the EU were suffering from sanctions and called on the EU to drop the policy of sanctions against Russia ${ }^{44}$. Hungarian Prime Minister Viktor Orban, who is often portrayed as the biggest supporter of Putin in Europe, also expressed his dissatisfaction with the sanction regime during a visit of Putin in Budapest in February 201745. Czech President Miloš Zeman talked about the ineffectiveness of sanctions against Russia and about the irreversibility of Russia's annexation of Crimea during a speech at the Council of Europe in October 201746. The reasons motivating the position of these countries is that the economic relations with Russia are deep and that their people consider important to maintain them. France, Germany and Italy, one of the most powerful EU member states, also raised their concerns in early 2018 about US sanctions targeting some of Russian oligarchs, companies and civil servants47 because they would disrupt European key industries' supply chains (especially in automotive and aerospace industries).

This element shows once more, similarly to what happened with sanctions targeting the energy sector, that the EU is not ready to bear additional costs in its aim of forcing Russia to change its strategy. In any case, the tendency of weakening support to the EU policy of sanctions against Russia from a rising number of EU member states (Hungary, Greece, Slovakia, Czech Republic, Bulgaria ${ }^{48}$ ) is a key element because, considering the specificity of the EU mechanism used to extend sanctions, it could quite easily lead to the lifting of EU sanctions against Russia.

\footnotetext{
4426 August 2016, "EU should drop Russia sanctions, Slovak PM says after meeting Putin", Reuters (https://www.reuters.com/article/us-ukraine-crisis-slovakia/eu-should-drop-russia-sanctions-slovak-pmsays-after-meeting-putin-idUSKCN1111A1).

${ }^{45}$ Byrne, A., 2 February 2017, "Orban joins Putin in attack on Russia sanctions", Financtial Times (https://www.ft.com/content/f1f4482a-e96b-11e6-893c-082c54a7f539) .

${ }^{46}$ Bechev, D., 11 October 2017, "Central and Eastern Europe's Pushback Against Sanctions on Russia", Atlantic Council (http://www.atlanticcouncil.org/blogs/new-atlanticist/central-and-eastern-europe-spushback-against-sanctions-on-russia).

${ }^{47}$ Weaver, C., Hille, K., 6 April 2018, "US imposes toughest Russian sanctions to date", Financial Times (https://www.ft.com/content/1e2086bc-3997-11e8-8b98-2f31af407cc8).

${ }^{48}$ Bechev, D., 11 October 2017, "Central and Eastern Europe's Pushback Against Sanctions on Russia", Atlantic Council (http://www.atlanticcouncil.org/blogs/new-atlanticist/central-and-eastern-europe-spushback-against-sanctions-on-russia).
}

Orientando. Temas de Asia Oriental. Sociedad, Cultura y Economía. Revista editada por el Centro de Estudios China-Veracruz de la Universidad Veracruzana, México (Centro de Estudios APEC) / año 10 / número 19/ 
EU sanctions against Russia could actually be lifted relatively easily since extending them requires a unanimous vote at the Council of the European Union ${ }^{49}$. This is only rarely mentioned but it means that each EU member state has a de facto veto power that could be used to lift all EU sanctions against Russia. In principle, Russia could use its good relations with only one EU member state in order to convince its authorities to use their veto power and lift sanctions. In practice, even if some countries' leaders officially stated their opposition to sanctions against Russia, they are not ready to use their veto power against the extension of sanctions. In fact, such a situation where one member state uses its veto power has never taken place ${ }^{50}$. One of the main reasons is the potential negative consequences for member states deviating from the common EU strategy. Western European member states, that are the strongest supporter of the sanction regime against Russia, occupy a central place in EU institutions and can use their position as a mean to pressure other member states to follow their strategy.

They can for example heavily influence the decision process of the European Bank for Reconstruction and Development (EBRD) ${ }^{51}$ and of the European Investment Bank $(\mathrm{EIB})^{52}$ that provide key financial support to development projects in many Eastern member states. Nevertheless, if a rising number of member states express doubts regarding the current sanction regime against Russia and given the veto power of each of them, it is reasonable to expect the common EU stance on sanctions against Russia to soften.

For its part, Russia insists on the retaliatory nature of the sanctions it implemented, which means that they could be lifted if the EU decides against extending its sanctions against Russia. Moreover, the Minsk Agreements do not mention the return of Crimea to

\footnotetext{
${ }^{49} \mathrm{EU}$ restrictive measures factsheet, 29 April 2014, Council of the European Union

${ }^{50}$ Luengo-Cabrera, J., Portela, C., 2015, "EU sanctions: exit strategies ", European Union Institute for Security Studies.

51 "Shareholders and Board of Governors", Structure and management, EBRD (http://www.ebrd.com/cs/Satellite?c=Content\&cid=1395236788928\&d=Mobile\&pagename=EBRD\%2F Content \%2FContentLayout)

52 "The Governance of the European Central Bank", 3 June 2015, EIB (http://www.eib.org/infocentre/publications/all/governance-of-the-eib.htm)
}

Orientando. Temas de Asia Oriental. Sociedad, Cultura y Economía. Revista editada por el Centro de Estudios China-Veracruz de la Universidad Veracruzana, México (Centro de Estudios APEC) / año 10 / número 19/ 
Ukraine $^{53}$, which seems very unlikely, and it would be possible for Russia to fulfill its engagement to fully implement the Minsk Agreements without bearing such a great cost. Similarly, if the Minsk Agreements were fully implemented, then the EU would be able to lift sanctions against Russia without giving the impression of weakening its position towards Russia. For all these reasons, the current tense relationship between Russia and the EU could quickly normalize and the obstacles to establish a more positive relationship could actually be overcome relatively easily. EU and US strategies regarding Russia are increasingly distinct ${ }^{54}$, which supports the idea that Russia and the EU become increasingly aware of the strong mutual economic and geopolitical interests from which they could both benefit with closer interaction.

Apart from the potential development of EU-Russian relations if both sides realize their common interest to foster a positive relationship, China might become one of Russia's key partner given the context of Western sanctions against Russia. As mentioned above, the rising and increasingly balanced trade between Russia and China is an important aspect of their relations but another development prospect of their relations is relevant to mention. Considering that the US and the EU have opted out from cooperation in a range of scientific and technological partnerships with Russia, China could indeed take on the role of Russia's privileged scientific and technological partner. This would be very relevant for Russia given China's experience of innovation in a wide range of sectors including automotive, telecommunications and renewables energy $\mathrm{y}^{55}$.

Closer business, technological and scientific cooperation between Russia and China might offset Russia's dependency from Western partners and would benefit both parts. While Russia would develop at a faster pace through diversification with better access to China's technological and financial resources, China could gain a powerful geopolitical ally particularly useful to fulfill its Silk Road initiative in Russia's region of influence and get a stronger voice on the international scene. Some of the latest news about China

\footnotetext{
${ }^{53}$ Lussato, C., 13 February 2015, "UKRAINE. La Crimée, grande oubliée des accords de Minsk", L'Obs (https://www.nouvelobs.com/monde/ukraine-la-revolte/20150213.OBS2483/ukraine-la-crimee-grandeoubliee-des-accords-de-minsk.html)

${ }^{54}$ Weaver, C., Hille, K., 6 April 2018, "US imposes toughest Russian sanctions to date", Financial Times (https://www.ft.com/content/1e2086bc-3997-11e8-8b98-2f31af407cc8)

${ }^{55}$ Zhou, Y., Lazonick, W., Sun, Y., 2016, "China as an Innovation Nation", University of Oxford Press.
}

Orientando. Temas de Asia Oriental. Sociedad, Cultura y Economía. Revista editada por el Centro de Estudios China-Veracruz de la Universidad Veracruzana, México (Centro de Estudios APEC) / año 10 / número 19/ 
show that its rising influence leads to the US and the EU getting worried about their national security (as in the recent case of Huawei ${ }^{56}$ ) or about Chinese's competing influence over traditional US and EU partner countries (in Eastern Europe ${ }^{57}$ or Africa ${ }^{58}$ for example).

What is also significant to mention is that Russia and China are increasingly jointly accused of competing with the US, and to a lesser extend with the EU, in their respective areas of comparative advantage. While China uses its huge financial resources to finance infrastructure projects all over the developing world and access US and EU markets with advanced technology at an attractive price, Russia employs its energy supplies to bring discord among Western allies (both among EU member states and in US-EU relations) as in the case of Nord Stream 2 and increasingly penetrates Africa through military exports and security advising ${ }^{59}$.

Some signs show that the relationship between China and Russia is deepening and this trend should continue considering the fact that they are both set aside on the international scene as countries trying to destabilize the world order. Nevertheless, under the presidency of Donald Trump, the US and the EU have developed more distinct views about world issues and this suggests a less positive future for EU-US relations and the realization of conflicting interests in some areas. The gradual decrease of European companies' access to Russian markets and Russia increasingly viewing China as a key partner might signal to the EU that its coercion power towards Russia is fading as SinoRussian relations improve.

The realization that tensed relations between the EU and Russia hurt European short and long run interests to the benefit of China will support the idea in the EU that resuming warm relations with Russia is necessary to maintain and improve EU influence in the

\footnotetext{
${ }^{56}$ Fildes, N., 26 February 2019, "US urges Europe to exclude Huawei from 5G network builds", Financial Times (https://www.ft.com/content/a4834900-39ce-11e9-b856-5404d3811663)

${ }^{57}$ Hopkins, V., 11 February 2019, "US moves to pull central and eastern Europe out of China-Russia orbit", Financial Times (https://www.ft.com/content/52bc0cca-2e24-11e9-8744-e7016697f225)

${ }^{58}$ Pilling, D., 13 December 2018, "Bolton accuses China and Russia of 'predatory practices' in Africa", Financial Times (https://www.ft.com/content/6645a26a-ff08-11e8-ac00-57a2a826423e)

${ }^{59}$ Foy, H., Astrasheuskaya, A., Pilling, D., "Russia: Vladimir Putin’s pivot to Africa", Financial Times (https://www.ft.com/content/a5648efa-1a4e-11e9-9e64-d150b3105d21)
}

Orientando. Temas de Asia Oriental. Sociedad, Cultura y Economía. Revista editada por el Centro de Estudios China-Veracruz de la Universidad Veracruzana, México (Centro de Estudios APEC) / año 10 / número 19/ 
global order. As this situation continues, Eurasian powers will prioritize better integration within the Eurasian continent and Russia could act as a connecting link between the EU and China given its key geopolitical position.

Orientando. Temas de Asia Oriental. Sociedad, Cultura y Economía. Revista editada por el Centro de Estudios China-Veracruz de la Universidad Veracruzana, México (Centro de Estudios APEC) / año 10 / número 19/ 